\title{
Social deixis analysis on the 1st Edition comic "The Platinum Sonata" written by Morita Fuji
}

\author{
Sugiarti $^{1}$, Herni Fitriani ${ }^{2}$ \\ ${ }^{1,2}$ Indonesian and art department of STKIP Nurul Huda South Sumatra \\ giarti@stkipnurulhuda.ac.id
}

\begin{abstract}
This study examines about social deixis on The Platinum Sonata Comics in the first edition.Communication is not only an exchange of the intention and content of the linguistic nature but it is a two-way relationship.By listening to the speaker's intention, we can recognize the characteristic of a person. The purpose of this research is to see the social deixis on The Platinum Sonata comics. This research uses qualitative approach method descriptions relating to deixis in The Platinum Sonata comics, noticing method and copying technic to obtain data by noticing to the language used. The data found was analyzed to reach the conclusion. By doing this kind of research, I could find out that there were 64 citations relating with social deixis. I did two periods of observations. In the first one I got 46 social citetations; 36 in words; and 10 in phrases. In the second observation, I got 18 deixis; 10 in the expression of manner; 8 in honorifics.
\end{abstract}

Keywords: Social deixis, the platinum Sonata Comic

\section{INTRODUCTION}

Comic is consisting of various serialized stories [1]. Moreover, it is also talking about humorous content. On the other hand, comic tells about social life. These kinds of characteristic should be recognized by the readers to strengthen their comprehension. Comic is a fiction story by nature. It is exposed by adapting some pictures to enhance the utterance intention. The content of the discourse is intended to deliver the message of the characters.

In delivering intention, people often use the pragmatics meaning. Pragmatics is the study of speakers' intention. The intention in pragmatics could be understood clear by listeners if both the speakers and listeners own similar perspective of deixes. Moreover, deixis is talking about the relationship between the uttered words and undefined reference [2]. The undefined reference could be a person (s), place, time, and social perspective.

The social deixis could be found in daily discourse. This kind of research focuses on the implementation of social deixis in the first edition of the Platinum sonata comic written by Morita Fuji. I would like to analyze the adaptation of pragmatics in the expression of social deixes in this comic.

\section{METHOD}

The method I used in this paper was qualitative descriptive in the form of content analysis.[3] said that content analysis was a strategy to catch literature message. In the other hand[4] said 
that qualitative method was a study procedure to get a descriptive data in the form of diction from the behavior of the observed people. The description here was in words. Therefore, the discussion of the paper would contain the citations to clarify the description.

Descriptive method was a method described the situation of evidence to drag conclusion by collecting, arranging, and classifying data. [5]Said that descriptive study was a study described the observed object by using data. Based on the statements of the authors, it could be said that the descriptive study is a procedure to solve the observed problem analyzed by describing the condition of an object or object of the study. It could be a person, institution, or anything else by nature.

\section{RESEARCH RESULT AND DISCUSSION}

Based on the purpose of the study, the result showed the existence of many social deixis content in the first Platinum Sonata comic written by Morita Fuji. For detail, I would like to explain it as follow:

1. Analysis of social deixis based on the formation of the words.

On the grammatical setting, words could come into morphology and zyntax. Nevertheless, the portion in morphology is greater than in syntax. [6]Said that a word is a free smallest unit. The word $\boldsymbol{k a k}$ for example. It is a free smallest word. The following conversation is the example of social diexis.

Customer: "KakTeru, more other pictures, please!"

Teru: "Ok then."

The expression $\boldsymbol{K a \boldsymbol { k }}$ is uttered by one of the custumers to Teru. The implementation of kak does not show the friendship. It is the common expression in the society to call the older person.

(1) The form of social deixis in phrase

If a phrase has two different usages, it means that it exceeds the usage of it. It could not be categorized as a phrase. I would like to show it in the following dialog.

Mr. Saechan: "Sawamurakun!!" (in a high pitch and angry)

"again and again! You always did something else when I was away. You are selalupayah"

TeruSawamurakun: “Sorry Boss.” (He bowed his head)

The phraseselalupayahused by Mr. Saechan when he was angry. This kind of social deixis is used to put someone under. On the other hand, Tanu called the skating arena owner with boss. It shows that the owner has a higher social status degree than Tanu.

2. The usage of social deixis analysis

(1) The social deixis usage on the politeness

The politeness has close relationship with the level ogivef friendship. It often happens in our neighborhood. To make it clear, I would like to give you an example.

Mr. Saechan: "Sawamurakun!” (in a high pitch and angry) 
"again and again! You always did something else when I was away. You are selalupayah"

TeruSawamurakun: "Sorry Boss." (He bowed his head)

The usage of social deixisBoss indicates the different level of social status. Tanu is as an employee and Mr. Saechan is as an employer or a boss. The employer has higher level of social status than the employee. So, the use of boss in this context shows the politeness.

(2) The usage of social deixis on honorific

There are some social status levels in the society. These kids of level start from inferior to superior or from the poorest one to the richest one. To clarify this perspective, I show the example.

Saechan father: "sawamurakun!" how dare! you are skating on high speed among the people. (the father was screaming, getting angry. And hitting his head)

Couch Toudou: "He is an atleet. (he was pointing at Tanu)

Mr. Saechan: "No!" he is just a part time worker. He often made mistakes. Go away! (he glared at Tanu)

The implementation of social deixis on a part time worker shows to differentiate the level of social status. A part time worker has a low status in the society especially in the field of work.

\section{CONCLUSION}

By doing an analysis of social deixes in the first edition of the Platinum Sonata comics, I found 64 citations concerning social deixes. From the two periods of analysis, I got 46 citations in the first one. 36 are in the form of words and 10 are in the form of phrases. In the second period, I found 18 citations. 10 are concerning the politeness expression and 8 are about the expression used in the level of social status. Moreover, social deixis used in the first edition of The Platibum Sonata comic is defined as the use of words and phrases with the uncertain references. The reference could tell about to whom the reference intended, when and where the reference takes place and delivered in other intention.

\section{REFERENCES}

[1] A. Meskin, "Defining Comics?," J. Aesthet. Art Crit., vol. 65, no. 4, pp. 369-379, Sep. 2007.

[2] G. Nunberg, "Indexicality and deixis,” Linguist. Philos., vol. 16, no. 1, pp. 1-43, Feb. 1993.

[3] N. K. Ratna, Teori, Metode, Dan teknik Penelitian Sastra. Yogyakarta: Pustaka Belajar, 2015.

[4] L. J. Meleong, Metode Penelitian Kualitatif. Jakarta: Rineka Cipta, 2012.

[5] Sugiyono, Metode Penelitian Pendidikan. Bandung: Alfabeta, 2008. 
[6] N. K. Astuti, "Bentuk dan Fungsi Deiksis Sosial pada Novel Kirti Njunjung Drajat Karya R. Tg. Jasawidagda,” Universitas Negeri Semarang, Semarang, 2015. 